\title{
Cultural, Practical, and Economic Value of Wild Plants: A Quantitative Study in The Bolivian Amazon 1
}

\author{
Victoria Reyes-García, Tomás Huanca, Vincent Vadez, \\ William LEONARD, DAVID WiLKIE
}

\begin{abstract}
Reyes-Garcia, Victoria (House 601;/\#17, ICRISAT, Patancheru 502 324, Andhra Prades, India; Tel: +91 (40) 3071 3682; Fax: +91 (40) 3071 3074/3075; e-mail: vreyes@ brandeis.edu), Tomás Huanca, Vincent Vadez (Sustainable International Development Program, Heller School for Social Policy and Management, Brandeis University, Waltham, MA 02454-9110), William Leonard (Department of Anthropology, Northwestern University, Evanston, IL 60208), and David Wilkie (Wildlife Conservation Society, 18 Clark Lane, Waltham, MA 02451-1823). Cultural, Practical, and Economic Value OF Wild Plants: A QuANTITATIVE Study IN THE Bolivian Amazon. Economic Botany xx:xx. 2005. Researchers have developed several indices to estimate the significance of plant species for humans. We build on previous methods in ethnobotany and anthropology to develop a new way to value plant species along three dimensions: cultural, practical, and economic. We used interview and observational data on the use of wild plants by the Tsimane', a foraging-horticultural society in the Bolivian Amazon. We calculated the cultural, practical, economic, and total values of 114 plant species from 46 families. We found a low correlation between the practical and the cultural values of species: some species rarely used were frequently mentioned in interviews, whereas some species frequently used were rarely mentioned in interviews. Indices of cultural, practical, and economic value measure different dimensions of the importance of plant species to society. The combination of the three indices offers a more comprehensive valuation of the significance of plants for humans than the use of only one index.
\end{abstract}

Key Words: Ethnobotanical knowledge, uses of plant, Tsimane' indigenous peoples, Bolivia, indices of cultural significance.

The interest in quantitative ethnobotany has grown steadily in the last two decades. Researchers have developed and applied quantitative methods to ethnobotanical data to test different hypotheses about the relation between plant species and humans. Some authors have developed indices of cultural significance that capture the importance of plants; these indices take into account cultural aspects, such as types of uses (Turner 1988) or taste of edible plants (Pieroni 2001). Other authors have proposed the use of indices that derive in part from ecological theory; they use the indices to determine the relative importance of different species or plant families to society (Begossi 1996; Benz et al. 2000; Phillips 1996). A third group of au-

\footnotetext{
${ }^{1}$ Received 15 July 2005; accepted 4 November 2005.
}

thors has estimated the economic value of forest goods for different ethnic groups (Godoy et al. 2002; Hecht, Anderson, and May 1988). What is lacking are studies that merge the different approaches to allow for a more comprehensive valuation of the importance of plants species for human societies. Our goal in this article is to take a first step in that direction.

Anthropologists and ethnobotanists have proposed several indices to estimate the cultural significance of plant species for humans. For example, Turner (1988) proposed an index of cultural significance that drew on the quality, intensity, and exclusivity of plant uses. Stoffle et al. (1990) modified the index proposed by Turner, adding a variable to measure the present use of the plant species. Recently, Pieroni (2001) proposed the inclusion of cultural variables, such as taste, to evaluate the importance of edible plants in a culture.

Economic Botany, 60(1), 2006, pp. 000-000.

(C) 2006, by The New York Botanical Garden Press, Bronx, NY 10458-5126 U.S.A. 
Ethnobotanists have constructed indices to measure the use value of plant species. For example, Phillips and Gentry (1993) defined the total use value of a species as a relation between the number of uses mentioned in interviews and the number of interviews conducted. Plants mentioned with more frequency were assigned more use value than plants mentioned with less frequency. Similarly, Begossi (1996) proposed the application of indices of ecological diversity to ethnobotanical data collected through survey questions. Building on this method, researchers have calculated diversity indices using data on the number of participants who mentioned a plant species during interviews (Figueiredo, Leitao-Filho, and Begossi 1997; Rossato, Leitao-Filho, and Begossi 1999).

Still other authors have estimated the economic value of forest goods for different human societies. Some authors have studied the value of specific plant resources. For example, Hecht and her colleagues describe the importance of the babassu palm among landless farmers in the Brazilian state of Maranhao (Hecht, Anderson, and May 1988). Other authors have calculated the financial benefits of tropical rain forests for local users and for the humanity (Godoy et al. 2002; Pimentel et al. 1997; Peters, Gentry, and Mendelsohn 1989).

Previous researchers have constructed indices to measure the value of plant species combining cultural and practical dimensions, but the elaboration of those indices presents two problems. First, researchers have mainly relied in data from surveys and interviews. For example, Turner (1988) included questions about frequency of use to capture the relative importance of different plant species in daily life. But responses to interview questions do not necessarily bear a strong relation to daily uses of plants (Begossi, Hanazaki, and Tamashiro 2002; Byg and Balslev 2001; Ladio and Lozada 2004; Reyes-García et al. 2005). The elaboration of a comprehensive index would be more accurate if it combined observational data with interview data. Second, although researchers have combined cultural and practical dimensions of plant uses, we still lack an index that also includes the economic value of plants.

In this article we build on previous methods in quantitative ethnobotany and economic anthropology to develop a new way to value different plant species for a cultural group. We overcome some of the problems faced by previous research by using both observations and interview data. Our index takes into account three dimensions: the cultural significance, the practical daily value, and the economic value of plant species. We estimate the cultural value of a plant species as a function of its potential uses and the number of participants reporting the plant. We estimate the practical value of a plant species as a function of the number of uses observed, the number of times the species was used, and the potential lifetime of the good made from the plant. Last, we estimate the economic value of a plant species as a function of the number of times the plant was used and the estimated price of the plant species.

Since the practical and economic values of a plant species are calculated from the same data, we expect a high correspondence between these two indices. We expect that the practical and the cultural values of a plant species would not bear a strong association with each other. For example, it is possible that a plant scores high in cultural value, as might happen if most people in a culture can name the plant, but low in practical value, as might happen if people rarely use the plant, and even then only for paltry ends. For the study we rely on information on the use and value of wild and semicultivated plants by Tsimane' indigenous peoples, a foraging and farming society in the Bolivian Amazon.

\section{Methods}

Two anthropologists, two biologists, and one agronomist conducted fieldwork during 18 months (May 1999-November 2000). The study forms part of a long-term research project in progress to measure the effect of markets on the quality of life of indigenous peoples.

\section{The People}

The Tsimane' are a foraging and farming society in the department of Beni in the Bolivian Amazon. The Tsimane' territory spreads from the foothills of the Andes to the northeast, reaching the edges of the Moxos savanna $\left(14^{\circ} 35^{\prime} \mathrm{S}-15^{\circ} 30^{\prime} \mathrm{S}\right.$; 66 $\left.23^{\circ} \mathrm{W}-67^{\circ} 10^{\prime} \mathrm{W}\right)$. Habitats in the Tsimane' territory range from wet to moist subtropical and gallery forests, some of which abut savannas (Killeen, García, and Beck 1993). Recent dissertations (Byron 2003) and publications (Vadez et al. 2004) provide de- 
tailed ethnographic information on the Tsimane', including description of traditional plant knowledge (Huanca 1999; Reyes-García 2001).

The Tsimane' economy centers on forest goods and subsistence agriculture (Godoy et al. 2002; Reyes-García 2001). Consumption of forest goods represents an average of U.S. $\$ 842 /$ household/year, or $45 \%$ of total Tsimane' household income. Tsimane' obtain game, fish, and wild and semicultivated plants from the forest all year. Tsimane' gather plants mostly near recently abandoned plots and during trips to the forest, and they use wild plants for food, firewood, medicines, house building, canoes, and crafts. The annual value of plants that Tsimane' gather (U.S.\$268/household) represents around $17 \%$ of the total income of a household (Reyes-García 2001).

Tsimane' share knowledge on uses of plant species (Reyes-García et al. 2003), but because they have different access to plant substitutes, their daily dependence on plants varies. We conducted the research in two villages at different distances from the local market town of San Borja (population about 19,000). The first village, Yaranda $\left(15^{\circ} 16.369^{\prime} \mathrm{S}, 6^{\circ} 50.838^{\prime} \mathrm{W}\right)$, lies about 50 kilometers in a straight line from the local town of San Borja, or three days canoeing upriver. The second study site, San Antonio $\left(14^{\circ} 48.698^{\prime} \mathrm{S}, 66^{\circ} 39.761^{\prime} \mathrm{W}\right)$, is 10 kilometers away from the town of San Borja, or about three hours walking at a normal pace.

\section{SAMPLING}

We used two different sampling strategies to collect information during interview and direct observations. For interview data, we selected a stratified sample of 24 participants in each village for a total of 48 interviews. We selected participants so they would include adult men and women of all ages. For observational data, we interviewed all people over 15 years of age in the two villages. We chose this as the cut-off age because most acquisition of ethnobotanical knowledge occurs before the age of about 15 (Hunn 2002; Ohmagari and Berkes 1997; Ruddle and Chesterfield 1977; Zarger 2002) and because at this age Tsimane' adolescents start forming their own households. The total sample for the study included 174 adults, of whom 80 $(46 \%)$ lived in the remote village of Yaranda and $94(54 \%)$ lived in the accessible village of San Antonio. The sample was almost evenly split between women (48\%) and men (52\%). The average age of subjects was 32.3 years $(\mathrm{sd}=15.67)$. Only two households in the remote village $(n=22)$ and three households in the accessible village $(n=27)$ refused to participate in the study. The total sample of adults grew by three people because outsiders married into the villages while the study took place.

\section{FREE Listing}

Free listing involved asking participants to spontaneously list the name of all the useful plants they knew and all the uses of each plant in their list. We asked each informant, "Can you tell me the names of all the useful wild plants you know?" and "What do you use them for?" Once informants stopped naming plants, we tried to prompt them to list more plants by asking, "Do you know any other wild plant that can be used as firewood?" Once they said they did not know any more plants that could be used for firewood, we asked the same question for medicine, dye, construction, canoe building, tools, or other uses.

\section{SCAN OBSERVATIONS}

To capture uses of plants, we conducted weekly interviews from November 1999 until October 2000. Every week, at the end of a day chosen at random, we visited each household and asked each adult present in the household to report the name of all the plants s/he had brought to the household during the previous 24 hours. We conducted a total of 66 scan observations, 34 in the village of San Antonio and 32 in the village of Yaranda. Information included interviews with 174 adults with an average of 9.06 interviews/adult $(\mathrm{sd}=7.36 ; \min =1 ; \max =32)$. During scan observations we recorded the following: (a) the Tsimane' name of the plant species brought in by each adult, and (b) the intended use of the plant species. Data collected with this method might be biased because the method does not capture plant species consumed outside the household, such as fruits or nuts that can be consumed in the forest.

\section{SPECIMEN IDENTIFICATION}

We collected voucher specimens for all plants reported as useful. We deposited voucher specimens at the Herbario Nacional de Bolivia, Universidad Mayor de San Andrés, La Paz. A key informant identified plant specimens in the 
local vernacular, and taxonomists from the herbarium provided the scientific nomenclature. We have described much of the Tsimane' ethnobotanical knowledge in a bilingual book in Tsimane' and Spanish (Nate, Ista, and ReyesGarcía 2000) and in two dissertations (Huanca 1999; Reyes-García 2001).

When conducting free listing and scan observations, we did not ask informants to identify voucher specimens corresponding to the plants named or brought to the household. Rather, we recorded the folk name of the species provided by the individual. Since we do not have individual-level correspondences between the folk names provided in free listing and scan observations and the scientific names, we refer to our data as ethnospecies (species based on folk name) rather than to plant species.

\section{Data Analysis}

We identified six categories of use: medicine, firewood, construction, tools, food, and other. Under the category "tools" we include mortars and grinding boards, food containers, mats, bags to store food, storage boxes, brooms, fabrics, bows, arrows, and weaving material. Under the category "other" we included uses that usually take place out of the household (e.g., canoe building) because those uses are not properly captured by scan observations. We also included uses reported with less frequency (e.g., dyes). Different uses of the same ethnospecies within the same category were counted as one, regardless of the number of uses within that given category. For example, a medicinal plant used for two different ailments was counted as one. For data from scans, we counted each ethnospecies brought by each adult as one, without taking into account the amount brought. When two different adults in the same household during the same day reported the same ethnospecies, we recorded them as two observations. Because local names of plants can change from one village to another, and because we do not have individual-level correspondence between the folk names provided in free listing and scan observations and the scientific names, we excluded from the analysis ethnospecies mentioned in only one village.

We calculated the cultural value of an ethnospecies using information from free listing, and we calculated the practical and economic values using observational information from scans. To calculate the cultural value of an ethnospecies, we used this formula:

$$
\mathrm{CV}_{\mathrm{e}}=\mathrm{Uc}_{e} * \mathrm{Ic}_{e} * \Sigma \mathrm{IUc}_{e}
$$

where $\mathrm{CV}_{\mathrm{e}}$ is the cultural value of ethnospecies $e$. $\mathrm{Uc}_{\mathrm{e}}$ is the total number of uses reported for ethnospecies $e$ divided by the six potential uses of an ethnospecies considered in the study (i.e., medicine, firewood, construction, tools, food, and other). Ic $\mathrm{c}_{\mathrm{e}}$ expresses the number of participants who listed the ethnospecies $e$ as useful divided by the total number of people participating in free listing. IUc $\mathrm{I}_{\mathrm{e}}$ expresses the number of participants who mentioned each use of the ethnospecies $e$ divided by the total number of participants. For example, if 15 participants listed ethnospecies $\mathrm{X}$ as medicinal, and 10 of them also listed it as edible, $\mathrm{IU}_{\mathrm{e}}=(15+10) / 48$. We follow Turner (1988), Stoffle et al. (1990), and Pieroni (2001) in multiplying the components of the index to amplify variations.

To calculate the practical value of an ethnospecies, we used a similar formula:

$$
\mathrm{PV}_{\mathrm{e}}=\mathrm{Up}_{\mathrm{e}} * \mathrm{Ip}_{\mathrm{e}} * \mathrm{DU} \mathrm{p}_{\mathrm{e}}
$$

where $\mathrm{PV}_{\mathrm{e}}$ is the practical value of ethnospecies $e$. $\mathrm{Up}_{\mathrm{e}}$ is the number of different uses observed for ethnospecies $e$ during scan observations divided by the six potential uses of an ethnospecies considered in the study. Ip $\mathrm{p}_{\mathrm{e}}$ expresses the number of times ethnospecies $e$ was brought to a household divided by the total number of informants participating in scan observations. The variable captures the share of participants who use the ethnospecies. DUp $\mathrm{p}_{\mathrm{e}}$ captures the duration of each use.

The calculation of the practical value is biased because some uses are more frequent than others. For example, people bring firewood to their households several times a week, but they might bring plants to craft tools only occasionally, as tools have a longer useful lifetime than firewood. Thus, in calculating the practical value of plants, ethnospecies used as firewood would appear more frequently because they have a shorter lifetime than plants to craft tools. The term DUp $_{e}$ should help redress the bias. Based on ethnographic fieldwork, we assigned a duration of one day to ethnospecies brought for food and firewood, seven days to ethnospecies brought for medicines, 30 days to ethnospecies brought to make tools or for other uses, and 90 days to ethnospecies brought for 
house construction. For example, if an ethnospecies was brought on three occasions as medicine ( $3 * 7$ days) and on two more occasions as an input to craft tools $(2 * 30$ days), the ethnospecies would have a duration of $1.23=$ $(21+60) / 66$ days, where 66 is the total number of scan observations.

To calculate the economic value of an ethnospecies we used the village price of the ethnospecies. For ethnospecies without a price, we used estimations from a previous study (Godoy et al. 2002), in which we asked villagers how much time it took them to find the good, multiplied the amount of time by the prevailing daily wage in the village, and assigned the resulting value to the ethnospecies. We used this formula:

$$
\mathrm{EV}_{\mathrm{e}}=\mathrm{Oe}_{\mathrm{e}} * \mathrm{Pe}_{\mathrm{e}}
$$

where $\mathrm{EV}_{\mathrm{e}}$ is the economic value of ethnospecies $e$. Oe $\mathrm{e}_{\mathrm{e}}$ is the number of observations for ethnospecies $e$, i.e., the total number of times the ethnospecies was brought to any household in the sample, and $\mathrm{Pe}_{\mathrm{e}}$ is the price of the ethnospecies.

We then calculate the total value of an ethnospecies $\left(\mathrm{V}_{\mathrm{e}}\right)$, as the sum of its cultural, practical, and economic values:

$$
\mathrm{V}_{\mathrm{e}}=\mathrm{CV}_{\mathrm{e}}+\mathrm{PV}_{\mathrm{e}}+\mathrm{EV}_{\mathrm{e}}
$$

To calculate the total value, we assigned a practical and economic value of " 0 " to ethnospecies that people mentioned in free listing but did not bring into their households during scan observations. Similarly, we assigned a cultural value of " 0 " to ethnospecies that Tsimane' brought to their households during scan observations but did not mention during free listing. Last, before adding data on cultural, practical, and economic values, we normalized the three indices. For example, to normalize the practical value, we divided the practical value of a given ethnospecies by the mean practical value of all ethnospecies.

Since some of our calculations rely on assumptions based on fieldwork, we re-estimated our indices under different scenarios and assumptions. First, we computed the various indices with data for each of the two villages of the study. Second, we recalculated the practical value by assigning a different duration to species with different uses: we assigned a duration of one day to ethnospecies brought for food and medicine, two days to ethnospecies brought for firewood, 30 days to ethnospecies brought for other uses, 90 days to ethnospecies brought for crafting tools, and 365 to ethnospecies brought for house building. Last, we included a new interaction term in equation [3] to capture the relative importance of each use. We assigned low values to uses that could be easily substituted by another ethnospecies with the same use. For example, we assigned a value of one to ethnospecies used for firewood because one wood species used for firewood can be easily substituted by another. We assigned an importance of two to construction and other uses, three to food, four to ethnospecies used to craft tools, and five to medicines.

\section{RESULTS}

\section{DESCRIPTION OF DATA}

Participants in free listing mentioned a total of 89 ethnospecies, which had a total of 221 different uses. During a year of scan observations, participants brought 100 ethnospecies to their households; the ethnospecies had a total of 178 different uses. The final sample of ethnospecies reported (i.e., either cited or observed more than two times) was 114 , from which only 61 were both cited and observed. The 114 plant species belonged to 46 different families. The most commonly represented families included Moracea $(n=11)$ and Palmae $(n=10)$. Twentysix ethnospecies were cited during free listing as having only one use, 22 as having two uses, 19 as having three uses, and 22 as having more than three uses. During scan observations, Tsimane' brought 45 ethnospecies with only one use, 38 with two uses, 12 with three different uses, and only five with more than three uses.

Figure 1 represents the distribution of uses cited and observed for the six categories of use.

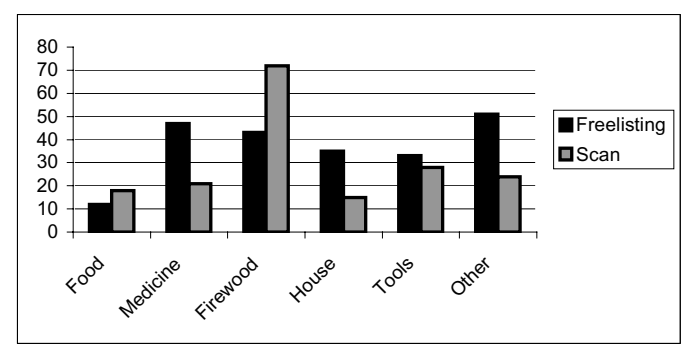

Fig. 1. Total number of uses cited (free listing) and observed (scan) for the different categories of use. 


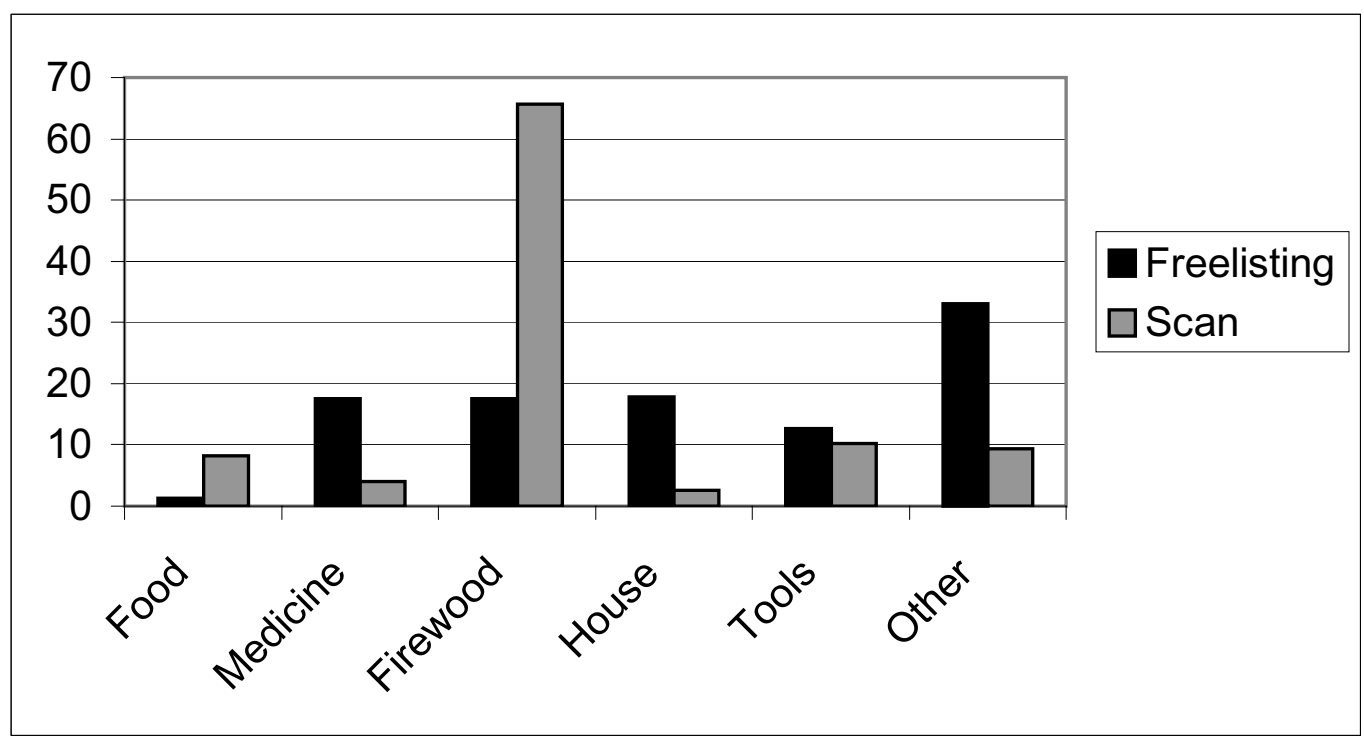

Fig. 2. Percentage distribution of uses of plants in free listing $(n=1,471)$ and scan observation $(n=1,550)$.

For most categories the number of uses reported was higher than the number of uses observed. For example, informants cited 47 different ethnospecies for medicine, but we only observed 21 ethnospecies being used as medicine. The two exceptions are ethnospecies in the categories of firewood and food. Tsimane' listed 43 ethnospecies as useful for firewood, but we observed the use of 72. Similarly, Tsimane' only listed the use of 12 ethnospecies as useful for food, but we observed the use of 18 .

We follow Phillips and Gentry (1993), Begossi (1996), and Pieroni (2001) and take into account in our calculations not only the number of uses of an ethnospecies, but also the number of people who reported using the ethnospecies. Figure 2 shows the percentage distri-

TABle 1. TOTAL ANNUAL ECONOMiC VAlue of ETHNOSPECIES IN SIX CATEGORIES OF USE (IN Bolivianos).

\begin{tabular}{lc}
\hline \hline Category & Bolivianos* \\
\hline Food & 4,268 \\
Medicine & 611 \\
Firewood & 8,413 \\
House & 2,694 \\
Tools & 3,976 \\
Other & 2,772
\end{tabular}

*1 U.S. $\$=6$ bolivianos, year 2000 bution of all the uses recorded in free listing $(\mathrm{n}=1,471)$ and scan observations $(\mathrm{n}=1,550)$. Data from free listing is more homogeneously distributed across the six categories of uses. For example, ethnospecies used for medicines, firewood, and house construction each represent about $18 \%$ of the total number of ethnospecies cited in free listing. In contrast, $66 \%$ of all the ethnospecies brought to Tsimane' households during scans were for firewood.

Table 1 shows the annual economic value of ethnospecies in each category of use. The ethnospecies used as firewood were the most valuable, whereas the category of lowest economic value was medicine (Table 1).

\section{Cultural, Practical, and Economic VALUeS}

The cultural value of the 114 ethnospecies in our sample ranged from 0 to 20.3 , the practical value ranged from 0 to 25.2 , and the economic value ranged from 0 to 11.64 . Thirty-one ethnospecies (or $27 \%$ of the total) had a cultural value of 0 , meaning that they were observed during scans but were not reported during free listings. Twenty-two ethnospecies (or 19\%) had a practical and economic value of 0 . The total value of ethnospecies varied between 0.004 and 42.1. We classified ethnospecies into four groups (Table 2). About 19\% of the ethno- 
TAble 2. Frequency and percentage distribution of the Cultural, PRACTiCAl, ANd eCONOMiC VAlues of 114 ethnospecies AMONG Tsimane’ Amerindians, Bolivia, 1999-2000.

\begin{tabular}{|c|c|c|c|c|c|c|c|c|}
\hline & \multicolumn{2}{|c|}{ Cultural Value } & \multicolumn{2}{|c|}{ Practical Value } & \multicolumn{3}{|c|}{ Economic Value } & Total Value \\
\hline Mean & \multicolumn{2}{|c|}{1} & \multicolumn{2}{|c|}{1} & \multicolumn{3}{|c|}{1} & 3 \\
\hline SD & \multicolumn{2}{|c|}{2.6} & \multicolumn{2}{|r|}{3.8} & \multicolumn{3}{|c|}{2.0} & 6.8 \\
\hline Min. & \multicolumn{2}{|c|}{0} & \multicolumn{2}{|c|}{0} & \multicolumn{3}{|c|}{0} & .004 \\
\hline Max. & \multicolumn{2}{|c|}{20.3} & \multicolumn{2}{|c|}{25.2} & \multicolumn{3}{|c|}{11.6} & 42.1 \\
\hline Range & Freq. & Percent & Freq. & Percent & Freq. & Percent & Freq. & Percent \\
\hline No value $(=0)$ & 31 & 27.19 & 22 & 19.30 & 22 & 19.30 & 0 & 0.00 \\
\hline Very $\operatorname{low}(<0.1)$ & 23 & 20.18 & 57 & 50.00 & 15 & 13.16 & 19 & 16.67 \\
\hline Low $(<1)$ & 38 & 33.33 & 23 & 20.18 & 53 & 46.49 & 45 & 39.47 \\
\hline High $(<10)$ & 20 & 17.54 & 9 & 7.89 & 23 & 20.18 & 42 & 36.84 \\
\hline Very high (>10) & 2 & 1.75 & 3 & 2.63 & 1 & 0.88 & 8 & 7.02 \\
\hline
\end{tabular}

species recorded fall in the category of very low total value (from 0 to 0.1 ), $39 \%$ had a low value (from 0.1 to 1 ), $37 \%$ had a high value (from 1 to 10 ), and $7 \%$ had a very high value (higher than 10).

We found a positive association between the three values. We regressed the cultural value against the practical value using robust standard errors to correct for heteroskedastic error terms and found a correlation coefficient of 0.217 between the two values $(p=0.004)$. In a regression of the cultural value against the economic value of ethnospecies we obtained similar results (coefficient $=0.333 ; \mathrm{p}=0.029$ ). In a third regression, we found that the association between the practical and economic value of ethnospecies was stronger than in the two previous regressions (coefficient $=1.398 ; \mathrm{p}<0.001$ ).

Table 3 contains information on the cultural, practical, economic, and total values of each ethnospecies recorded. Ethnospecies are listed from higher to lower total value. Most ethnospecies with "very low total value" $\left(\mathrm{V}_{\mathrm{e}}<0.1\right)$ were either cited or observed on few occasions, but were not captured by both methods used. Only two of the ethnospecies in this group were both cited and observed. Most of the ethnospecies reported as medicinal fall in the group of ethnospecies with "low total value" $\left(1>V_{\mathrm{e}}>0.1\right)$. Most ethnospecies with "high total value" $\left(10>\mathrm{V}_{\mathrm{e}}>1\right)$ were listed and observed as having at least two but also three or more different uses. Ethnospecies in this group were cited as having mainly one use, either firewood, house building, or other, but most practical value of ethnospecies in this group is given by use as firewood. Four of the ten ethnospecies recorded in the Palmae family and four of the ten in the Moraceae family fall in this group. Ethnospecies with "very high total value" $\left(\mathrm{V}_{\mathrm{e}}>10\right)$ were widely cited and observed as having many different uses. For example, Attalea phalerata, the species with a highest total value, was recorded with all the uses except food. Other species in this group include Gynerium sagittatum and Geonoma deversa, the preferred material for roofing, which is also an important commodity in the area. Swietenia macrophylla falls into this group and is one of the most commonly cited plants, but we did not observe any use of the plant during our research. Other ethnospecies in the group are Hura crepitans, Bactris gassipae, and $\mathrm{Ce}$ cropia concolor Willd. Three of the ethnospecies in this group belong to the Palmae family.

To test how sensitive our results are to the assumptions made for the computation of values, we regressed the values reported in Table 3 against values found under four different assumptions. We found that the coefficients were high, positive, and statistically significant (Table 4), so we conclude that the model is robust to data collected in both communities and to different definitions of practical value.

\section{Discussion and Conclusions}

Ethnobotanical quantitative indices have been developed because qualitative ethnobotanical data (i.e., lists of plants and their uses) do not allow one to identify the special cultural or economic role of a plant species to society. In this article, we have taken a first step in developing a new way to assess the value of different
$-\mathrm{S}$ 
Table 3. Cultural, practical, economic, and total values of 114 Plant Species among Tsimane’ Amerindians, Bolivia, $1999-2000$.

\begin{tabular}{|c|c|c|c|c|c|c|c|}
\hline Scientific Name & Family & Tsimane' Name & Voucher & $\mathbf{v}_{\mathrm{e}}$ & $\mathbf{C V}_{\mathrm{e}}$ & $\mathbf{P V}_{\mathrm{e}}$ & $\mathbf{E V}_{\mathrm{e}}$ \\
\hline \multicolumn{8}{|l|}{ Very high total value $\left(V_{e}>10\right)$} \\
\hline Attalea phalerata C. Martius ex Sprengel & Palmae & Mana'i & TH277 & 42.11 & 7.85 & 22.61 & 11.64 \\
\hline Gynerium sagittatum (Aublet) P. Beauv & Poaceae & Shuru' & EP050 & 41.64 & 8.29 & 25.17 & 8.18 \\
\hline Geonoma deversa (Poiteau) Kunth & Palmae & Cajtafa' & TH191 & 28.39 & 0.54 & 20.90 & 6.96 \\
\hline Swietenia macrophylla (King) & Meliaceae & Chura' & Gullison, 1994 & 20.27 & 20.27 & 0.00 & 0.00 \\
\hline Bactris gassipae & Palmae & $V a^{\prime} i j$ & TH526 & 16.65 & 11.89 & 0.87 & 3.89 \\
\hline Hura crepitans $\mathrm{L}$. & Euphorbiaceae & Conojfoto' & TH098 & 15.57 & 8.63 & 4.99 & 1.95 \\
\hline Indetemined & Flacourtiaceae & Ava Ava & TH099 & 15.03 & 0.77 & 6.18 & 8.08 \\
\hline Cecropia concolor Willd. & Moraceae & Tyiruru' & TH330 & 13.30 & 0.78 & 4.16 & 8.35 \\
\hline \multicolumn{8}{|l|}{ High total value $\left(10>V_{e}>1\right)$} \\
\hline Rheedia cf. brasiliensis (Mart) Planch \& Triana & Guttiferae & Tsocoi & TH130 & 9.49 & 0.94 & 0.10 & 8.45 \\
\hline Heliocarpus americanus L. & Tiliaceae & Mü & TH078 & 8.79 & 0.37 & 2.11 & 6.32 \\
\hline Ochroma pyramidale (Cav. ex Lam) Urban & Bombacaceae & Cajñere’ & TH189 & 7.89 & 1.31 & 4.23 & 2.36 \\
\hline Scheleea sp. & Palmae & Bitere & TH447 & 7.82 & 0.00 & 5.56 & 2.26 \\
\hline Cedrela odorata & Meliaceae & Siyamo' & TH070 & 7.03 & 7.03 & 0.00 & 0.00 \\
\hline Thoracocapus bissectus (Vell.) Harling & Cyclanthaceae & Tapi & TH039 & 6.72 & 0.02 & 4.22 & 2.48 \\
\hline Iriartea deltoidea & Palmae & Ojdo & TH301 & 5.75 & 1.95 & 3.08 & 0.72 \\
\hline Callophyllum sf. Longiphyllum Willd. & Guttiferae & Yäjdye'dye & TH472 & 4.70 & 4.70 & 0.00 & 0.00 \\
\hline Cecropia sp. & Moraceae & Tsanaj & TH410 & 3.98 & 0.00 & 0.81 & 3.17 \\
\hline Inga punctata Willd. & Leguminosae-Mim & Vishi'ri & AN019 & 3.90 & 0.00 & 0.54 & 3.36 \\
\hline Inga cerstediana Benth. ex Seeman & Leguminosae-Mim & Cu’na & TH227 & 3.61 & 2.48 & 0.21 & 0.92 \\
\hline Astrocaryum mигитиги C. Martius & Palmae & Shibo' & TH360 & 3.60 & 1.31 & 0.15 & 2.14 \\
\hline Guarea aff. guidonia (L.) Sleumer & Meliaceae & Vapi & TH441 & 3.51 & 2.96 & 0.06 & 0.50 \\
\hline Virola sp. & Myristicaceae & $\mathrm{Cam}$ & TH068 & 3.32 & 3.04 & 0.06 & 0.22 \\
\hline Caesaria sylvestris $\mathrm{Sw}$ & Flacourtiaceae & Tavo'tavo' & TH396 & 3.26 & 1.90 & 0.22 & 1.13 \\
\hline Xylopia aff. ochrantha Mart & Annonaceae & Tutyi' & TH425 & 3.02 & 2.40 & 0.15 & 0.47 \\
\hline Terminalia oblonga (Ruiz \& Pavon) Steudel & Combretaceae & Cotison & TH008 & 2.38 & 1.43 & 0.10 & 0.85 \\
\hline Picramnia sellowii Planch & Simaroubaceae & Itsi & TH013 & 2.37 & 1.66 & 0.06 & 0.65 \\
\hline Clarisia racemosa & Moraceae & Vavai & TH090 & 2.37 & 2.33 & 0.00 & 0.03 \\
\hline Ficus sp. & Moraceae & Muj pe & TH018 & 2.32 & 1.10 & 0.20 & 1.02 \\
\hline Acacia loretensis & Leguminosae-Mim & Shara' & TH350 & 2.12 & 0.80 & 0.34 & 0.98 \\
\hline Vernonia patens $\mathrm{BHK}$ & Compositae & O'ojvi & AN001 & 2.12 & 0.05 & 1.35 & 0.72 \\
\hline Sida rhombifolia L. & Malvaceae & Chip & AN006 & 1.89 & 0.15 & 0.63 & 1.11 \\
\hline Triplaris americana $\mathrm{L}$. & Polygonaceae & Chij & TH083 & 1.88 & 0.88 & 0.10 & 0.90 \\
\hline Serjania tenuifolia Radlk & Sapindaceae & Vashi & TH089 & 1.75 & 0.00 & 0.56 & 1.19 \\
\hline Leonia racemosa C. Martius & Violaceae & RojRo’' & TH081 & 1.75 & 0.00 & 0.84 & 0.91 \\
\hline
\end{tabular}


Table 3. Continued.

\begin{tabular}{|c|c|c|c|c|c|c|c|}
\hline Scientific Name & Family & Tsimane' Name & Voucher & $\mathbf{v}_{\mathrm{e}}$ & $\mathbf{C V}_{\mathrm{e}}$ & $\mathbf{P V}_{\mathrm{e}}$ & $\mathbf{E V}_{\mathrm{e}}$ \\
\hline Tetragastris altissima (Aublet) Swart & Burseraceae & $N a^{\prime} f a$ & TH125 & 1.73 & 1.73 & 0.00 & 0.00 \\
\hline Sloanea obtusifolia & Elaeocarpaceae & Shejsherena & TH354 & 1.61 & 1.47 & 0.00 & 0.14 \\
\hline Inga sp. & Leguminosae-Mim & Virui & TH088 & 1.61 & 0.00 & 0.21 & 1.39 \\
\hline Cecropia membranacea Trécul & Moraceae & Tyej & TH426 & 1.54 & 0.00 & 0.01 & 1.53 \\
\hline Pouteria torta (Mart.) Radlk. & Sapotaceae & Cojma & EP026 & 1.53 & 0.91 & 0.18 & 0.43 \\
\hline Inga sp. & Leguminosae-Mim & Shabut & ТH030 & 1.50 & 0.00 & 0.17 & 1.33 \\
\hline Tremma integerrima (Beurl) Standley & Ulmaceae & Dyotoj & TH011 & 1.45 & 0.10 & 0.50 & 0.86 \\
\hline Tephrosia vogelii J.D. & Leguminosae-Pap & Chito' & TH371 & 1.45 & 0.02 & 0.52 & 0.92 \\
\hline Uncaria guianensis (Aubl.) Gremlin & Rubiaceae & Oveto' & TH044 & 1.40 & 1.11 & 0.02 & 0.27 \\
\hline Ruizodendron ovale (Ruiz \& Pavon) R.E. Fries & Annonaceae & $\tilde{N} e j \tilde{N} e j$ & TH093 & 1.28 & 0.00 & 0.16 & 1.12 \\
\hline Maclura tinctorea & Moraceae & Cotyij' Cotyij' & TH224 & 1.22 & 0.80 & 0.01 & 0.41 \\
\hline Socratea exorrhiza & Palmae & Vijri & TH452 & 1.17 & 0.37 & 0.23 & 0.57 \\
\hline Indetermined & Flacourtiaceae & Vajbason & TH153 & 1.11 & 0.73 & 0.05 & 0.33 \\
\hline Ficus killipii & Moraceae & Simaj & TH037 & 1.09 & 0.80 & 0.01 & 0.27 \\
\hline Erythrina sp. & Leguminosae-Pap & Cajpa' & TH190 & 1.04 & 0.00 & 0.01 & 1.04 \\
\hline $\begin{array}{l}\text { Lunania parviflora Spruce ex Benth } \\
\text { Low total value }\left(\mathbf{1}>V_{\mathbf{e}}>\mathbf{0 . 1}\right)\end{array}$ & Flacourtiaceae & Cajnason & AN013 & 1.01 & 0.22 & 0.04 & 0.75 \\
\hline Indetermined & Moraceae & Висиј & TH182 & 0.88 & 0.48 & 0.01 & 0.40 \\
\hline Celtis schippii Standley & Ulmaceae & Nove' & EP011 & 0.87 & 0.00 & 0.08 & 0.79 \\
\hline Ampelocera sp. & Ulmaceae & Shepi' & TH355 & 0.78 & 0.27 & 0.07 & 0.44 \\
\hline Iryanthera juruensis Warb. & Myristicaceae & Po'cocos & AN014 & 0.76 & 0.17 & 0.04 & 0.54 \\
\hline Cordia cf. tetrandra Aublet & Boraginaceae & Juparety casmo & EP055 & 0.73 & 0.00 & 0.16 & 0.57 \\
\hline Inga sp. & Leguminosae-Mim & Cojno’no & TH007 & 0.73 & 0.00 & 0.04 & 0.69 \\
\hline Hymenaea courbaril L. & Leguminosae-Pap & Bejqui & TH072 & 0.69 & 0.47 & 0.00 & 0.21 \\
\hline Ficus cf. insipida Willd. & Moraceae & Titij & TH123 & 0.68 & 0.45 & 0.00 & 0.23 \\
\hline Petiveria alliacea $\mathrm{L}$. & Phytolaccaceae & Eré & ЕР064 & 0.67 & 0.12 & 0.05 & 0.50 \\
\hline Tessaria integrifolia $\mathrm{R} \& \mathrm{P}$ & Compositae & Sijta & TH383 & 0.64 & 0.56 & 0.00 & 0.00 \\
\hline Pilocarpus sp. & Rutaceae & Tam'tac & TH398 & 0.63 & 0.49 & 0.01 & 0.14 \\
\hline Schizolobium sp. & Leguminosae-Cae & Co'shi' & TH211 & 0.61 & 0.61 & 0.00 & 0.00 \\
\hline Passiflora sp. & Passifloraceae & Shiveni & EP012 & 0.59 & 0.59 & 0.00 & 0.00 \\
\hline Jessenia bataua & Palmae & Jajru' & TH265 & 0.54 & 0.37 & 0.03 & 0.14 \\
\hline Sapindus saponaria $\mathrm{L}$. & Sapindaceae & Shevijriqui & TH107 & 0.52 & 0.52 & 0.00 & 0.00 \\
\hline Neea af. spruceana Heirmel & Nyc & Vishi Vishi & TH458 & 0.49 & 0.41 & 0.00 & 0.09 \\
\hline Indetermined & & Javujna & EP016 & 0.48 & 0.17 & 0.01 & 0.30 \\
\hline Annona reticulata $\mathrm{L}$. & Annonaceae & Pise’rej & TH118 & 0.47 & 0.00 & 0.01 & 0.46 \\
\hline Acalypha sp. & Euphorbiaceae & Cabij' & TH186 & 0.47 & 0.00 & 0.09 & 0.38 \\
\hline
\end{tabular}


Table 3. Continued.

\begin{tabular}{|c|c|c|c|c|c|c|c|}
\hline Scientific Name & Family & Tsimane' Name & Voucher & $\mathbf{v}_{\mathrm{e}}$ & $\mathbf{C V}_{\mathrm{e}}$ & $\mathbf{P V}_{\mathrm{e}}$ & $\mathbf{E V}_{\mathrm{e}}$ \\
\hline Carludovica palmata & Cyclanthaceae & Tso'vety & TH417 & 0.47 & 0.09 & 0.04 & 0.34 \\
\hline Pera benensis (Rusby) & Euphorbiaceae & Apaijniquij & TH161 & 0.46 & 0.23 & 0.00 & 0.23 \\
\hline Piper glabratum Kunth & Piperaceae & Чриуи' & TH046 & 0.43 & 0.00 & 0.16 & 0.27 \\
\hline Ceiba sp. & Bombacaceae & Fuj fuj & TH254 & 0.41 & 0.00 & 0.02 & 0.40 \\
\hline Acalypha benensis Britton & Euphorbiaceae & Shoijno & AN004 & 0.38 & 0.00 & 0.06 & 0.32 \\
\hline Pseudolmedia laevis (Ruiz \& Pavon) J.F. Macbr. & Moraceae & Ijsi’ta & EP023 & 0.37 & 0.00 & 0.00 & 0.37 \\
\hline Pterocarpus sp. & Leguminosae-Pap & Naba'ba & ЕР021 & 0.37 & 0.00 & 0.09 & 0.28 \\
\hline Canna bangii Krauz & Cannabaceae & $B u^{\prime} b u i$ & ЕР049 & 0.37 & 0.37 & 0.00 & 0.00 \\
\hline Monotogma cf. laxun (P \& E) K Schum & Marantaceae & Su'rij & TH387 & 0.37 & 0.00 & 0.10 & 0.27 \\
\hline Trichilia rubra $\mathrm{CDC}$ & Meliaceae & Dyabaj-dyabaj & TH243 & 0.34 & 0.18 & 0.01 & 0.15 \\
\hline Abarema sp. & Leguminosae-Mim & Cujtyuju & EP015 & 0.30 & 0.00 & 0.01 & 0.30 \\
\hline Capsicum frutescens $\mathrm{L}$. & Solanaceae & Shishi & AN005 & 0.29 & 0.15 & 0.01 & 0.13 \\
\hline Bactris major Jacq. Martius & Palmae & Cocojpe' & TH 216 & 0.26 & 0.00 & 0.05 & 0.22 \\
\hline Duguetia spixiana Mart & Annonaceae & Veya & TH448 & 0.25 & 0.11 & 0.00 & 0.14 \\
\hline Aniba canelilla (H.B.K.) Mez & Lauraceae & Chorecho' & TH206 & 0.24 & 0.15 & 0.01 & 0.09 \\
\hline Sloanea guianensis (Aublet) Bentham & Elaeocarpaceae & Faj Faj & TH499 & 0.22 & 0.13 & 0.00 & 0.09 \\
\hline Clarisa cf. biflora Ruiz \& Pavon & Moraceae & Mu’suruj & TH020 & 0.20 & 0.11 & 0.00 & 0.09 \\
\hline Syagrus sancona Karsten & Palmae & Batin & TH170 & 0.17 & 0.17 & 0.00 & 0.00 \\
\hline Heliconea & Musaceae & Paya & TH313 & 0.17 & 0.00 & 0.12 & 0.04 \\
\hline Indetermined & Rubiaceae & Mito & TH279 & 0.15 & 0.02 & 0.00 & 0.12 \\
\hline Bixa orellana $\mathrm{L}$. & Bixaceae & Faj & TH251 & 0.15 & 0.04 & 0.01 & 0.10 \\
\hline Guadua spp. & Gramineae & Ton' & TH503 & 0.13 & 0.13 & 0.00 & 0.00 \\
\hline Matayba sp. & Sapindaceae & Vepi & EP040 & 0.13 & 0.00 & 0.00 & 0.12 \\
\hline Zanthoxylum sp. & Rutaceae & Vayuna & TH053 & 0.11 & 0.00 & 0.01 & 0.11 \\
\hline Bixa urucurana Willdenow & Bixaceae & I'fo' & TH258 & 0.11 & 0.02 & 0.02 & 0.07 \\
\hline Tapirira guianensis Aublet & Anacardiaceae & Shonoj & TH069 & 0.10 & 0.00 & 0.00 & 0.10 \\
\hline \multicolumn{8}{|l|}{ Very low total value $\left(\mathrm{V}_{\mathrm{e}}<0.1\right)$} \\
\hline Casearia & Flacourtiaceae & Birina & TH109 & 0.09 & 0.00 & 0.00 & 0.09 \\
\hline Pouteria cf. torta (Mart) Radlk & Sapotaceae & So'rocaj & TH038 & 0.08 & 0.01 & 0.00 & 0.07 \\
\hline Sparattanthelium burchellii Rusby & Hennandaceae & Vayori & AN023 & 0.07 & 0.00 & 0.00 & 0.07 \\
\hline Spondias mombin L. & Anacardiaceae & Мосо' & TH122 & 0.07 & 0.01 & 0.00 & 0.06 \\
\hline Pouteria reticulata (Engler) Eyma & Sapotaceae & Ujfare & TH001 & 0.07 & 0.07 & 0.00 & 0.00 \\
\hline Salix humboldtiana Willd. & Salicaceae & Sivin & TH389 & 0.06 & 0.06 & 0.00 & 0.00 \\
\hline Fevillea sp. & Cuc & Dyincava' & TH076 & 0.06 & 0.06 & 0.00 & 0.00 \\
\hline
\end{tabular}




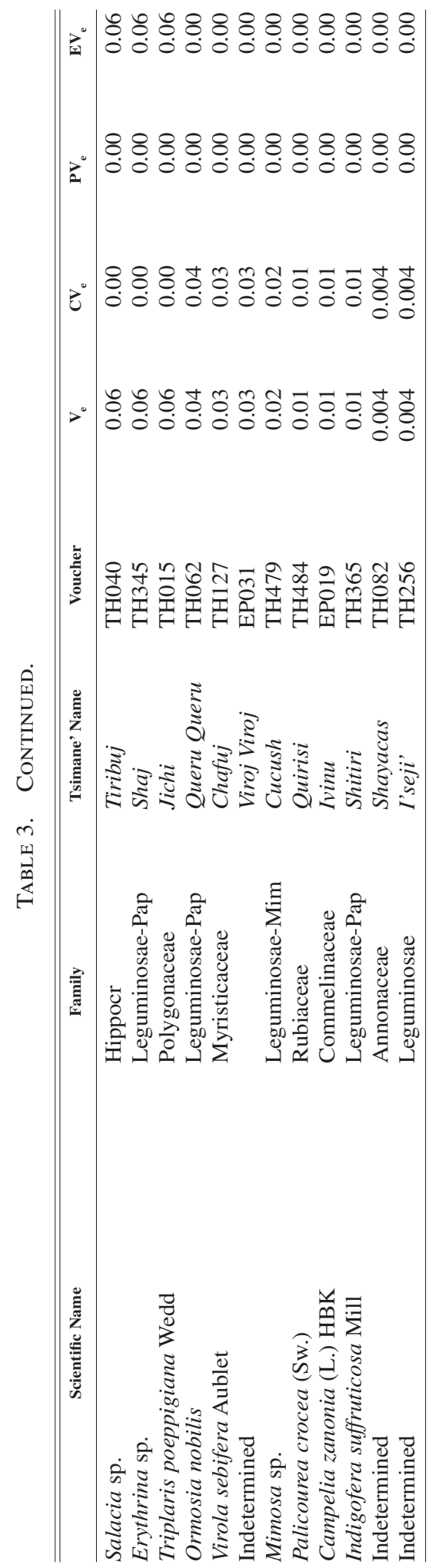

plant species taking into account the cultural, practical, and economic values of plant species to people of one culture.

The cultural value of a plant species does not necessarily correspond with its practical or economic values. Some species, such as Swietenia macrophylla, are rarely used but frequently mentioned in interviews, whereas other species, such as Guazuma ulmifolia, are frequently used but rarely mentioned during interviews. Therefore, indices measuring the cultural and practical values capture different aspects of the importance of a plant species for humans. The index of cultural value captures the theoretical importance of a plant for a given culture, whereas the index of practical value reflects the relative intensity of use of a plant in daily life. Furthermore, the score of a plant in one index might change independently from the score of the plant in the other index. For example, differences between cultural and practical indices might reflect changes in the availability of species. Swietenia macrophylla and Cedrela odorata are two precious woods in the area with many previous uses among the Tsimane'. The diversity of uses of those species made them culturally significant, but the two species have been logged almost to extinction (Gullison 1995, 1996), which explains their low practical value at present.

We found a high correspondence between the practical and economic values of ethnospecies, which might be partially explained because we calculated those values using the same data from scan observations. Scan observations reflect the importance of plants for household consumption but are not a reliable method to estimate cash income from forest products, because many of the forest products that have a commercial value never enter the household, and therefore are not captured by scans. For example, our data might underestimate the importance of Geonoma deversa in the Tsimane' economy. Leaves from that palm are used to build roofing mats, yet an important part of the extraction and processing does not occur in the household but rather in camps near the area where the palm grows. Our data biases the economic importance of plants toward their consumption value and underestimates their value as a source of monetary income.

In sum, the various indices presented here measure different aspects of the importance of 
TABle 4. Sensitivity anAlysis: REgressions of the VAlues Reported in TABle 3, Against RECOMPUTED INDICES FOR DIFFERENT ASSUMPTIONS.

\begin{tabular}{|c|c|c|c|c|c|c|c|c|}
\hline \multirow[b]{2}{*}{ Type of Value } & \multicolumn{2}{|c|}{ San Antonio ${ }^{\mathrm{a}} \mathrm{N}=\mathbf{8 1}$} & \multicolumn{2}{|c|}{ Yaranda $^{\mathrm{b}} \mathrm{N}=109$} & \multicolumn{2}{|c|}{ Duration $^{\mathrm{c}} \mathrm{N}=114$} & \multicolumn{2}{|c|}{ Intensity ${ }^{\mathrm{d}}=114$} \\
\hline & Coeff & $\mathrm{p}$ & Coeff & $\mathrm{p}$ & Coeff & $\mathrm{p}$ & Coeff & $\mathrm{p}$ \\
\hline Cultural & 1.11 & $<0.000$ & 0.99 & $<0.000$ & $\wedge$ & & $\wedge$ & \\
\hline Practical & 0.52 & $<0.000$ & 0.54 & $<0.000$ & 0.91 & $<0.000$ & 0.88 & $<0.000$ \\
\hline Economic & 0.69 & $<0.000$ & 0.64 & $<0.000$ & $\wedge$ & & $\wedge$ & \\
\hline Total Value & 0.69 & $<0.000$ & 0.66 & $<0.000$ & 0.96 & $<0.000$ & 0.94 & $<0.000$ \\
\hline
\end{tabular}

$\wedge$ Indicates that the values were identical to the values in Table 3.

${ }^{a}$ Data from San Antonio only.

${ }^{\mathrm{b}}$ Data from Yaranda only.

${ }^{\mathrm{c}}$ New assumptions for the parameter DUp in expression [2].

${ }^{\mathrm{d}}$ New parameter in expression [2] capturing whether a use is easily substituted or not.

plants for people. Previous indices that rely exclusively on information from interviews fail to pick up the practical value and the economic importance of plant species. Similarly, observational data fails to capture plant species without much cultural value, but with frequent use in daily life. Information depending on only one of the three indices biases our understanding of the importance of plant species for people. The combination of the three indices offers a more comprehensive valuation of the significance of plants for humans than one might obtain from using only one index.

\section{Acknowledgments}

Funds for this research came from the National Science Foundation (SBR-9731240 and SBR-9904318), the John D. and Catherine T. MacArthur Foundation, Conservation, Food and Health Foundation, the Central de Pueblos Indígenas del Oriente Boliviano, and the Wenner-Gren Foundation (Gr-7250). We would like to thank Wendy Townsend for encouraging the research. We thank the Gran Consejo Tsimane', L. Apaza, E. Byron, D. Ista, A. Nate, J. Pache, and E. Pérez for their support with fieldwork and logistics, and ICRISAT-Patancheru for providing office facilities to Reyes-García. We thank R Godoy, W. McClatchey, D. Moerman, and one anonymous reviewer for comments on previous versions of the article.

\section{Literature Cited}

Begossi, A. 1996. Use of ecological methods in ethnobotany: Diversity indices. Economic Botany 50:280-289.
, N. Hanazaki, and J. Tamashiro. 2002. Medicinal plants in the Atlantic Forest (Brazil): Knowledge, use, and conservation. Human Ecology 30:281-299.

Benz, B. F., J. Cevallos, F. Santana, J. Rosales, and S. Graf. 2000. Losing knowledge about plant use in the sierra de Manantlan Biosphere Reserve, Mexico. Economic Botany 54:183-191.

Byg, A., and H. Balslev. 2001. Traditional knowledge of Dypsis fibrosa (Aracaceae) in Eastern Madagascar. Economic Botany 55:263-275.

Byron, E. 2003. Market integration and health: The impact of markets on the nutritional status, morbidity, and diet of the Tsimane' Amerindians of lowland Bolivia. Ph.D. dissertation, University of Florida, Gainesville.

Figueiredo, G. M., H. Leitao-Filho, and A. Begossi. 1997. Ethnobotany of Atlantic forest coastal communities: Diversity of plant uses at Sepetiba Bay (SE Brazil). Human Ecology 25:353-360.

Godoy, R., H. Overman, J. Demmer, L. Apaza, E. Byron, T. Huanca, W. Leonard, E. Perez, V. ReyesGarcía, V. Vadez, D. Wilkie, A. Cubas, K. McSweeny, and N. Brokaw. 2002. Local financial benefits of rain forests: Evidence from Amerindian societies in Bolivia and Honduras. Ecological Economics 40:397-409.

Gullison, E. 1995. Conservation of tropical forests through the sustainable production of forest products: The case of mahogany (Swietenia macrophylla King) in the Chimanes Forest, Beni, Bolivia. Ph.D. thesis, Princeton University, New Jersey.

- S. N. Panfil, J. Strouse, and S. Hubbell. 1996. Ecology and management of mahogany (Swietenia macrophylla King) in the Chimanes Forest, Beni, Bolivia. Botanical Journal of the Linnean Society 122(1):9-34.

Hecht, S., A. Anderson, and P. May. 1988. The subsidy from nature: Shifting cultivation, succes- 
sional palm forests and rural development. Human Organization 47:25-35.

Huanca, T. 1999. Tsimane' indigenous knowledge. Swidden Fallow Management and Conservation. Ph.D. dissertation, University of Florida, Gainesville.

Hunn, E. S. 2002. Evidence for the precocious acquisition of plant knowledge by Zapotec children. Pages 604-613 in J.R. Stepp, F.S. Wyndham, and R. Zarger, eds. Ethnobiology and biocultural diversity. International Society of Ethnobiology, Athens, Georgia.

Killeen, T., E. García, and S. Beck. 1993. Guía de Arboles de Bolivia. Herbario Nacional de Bolivia y Missouri Botanical Gardens, La Paz, Bolivia.

Ladio, A., and M. Lozada. 2004. Patterns of use and knowledge of wild edible plants in distinct ecological environments: A case study of a Mapuche community from northwestern Patagonia. Biodiversity and Conservation 13:1153-1173.

Nate, A., D. Ista, and V. Reyes-García. 2000. Plantas útiles y su aprovechamiento en la comunidad Tsimane' de Yaranda. CIDOB-DFID, Santa Cruz, Bolivia.

Ohmagari, K., and F. Berkes. 1997. Transmission of indigenous knowledge and bush skills among the Western James Bay Cree women of Subarctic Canada. Human Ecology 25:197-222.

Peters, C.M., A.H. Gentry, and R. Mendelsohn. 1989. Valuation of a tropical forest in Peruvian Amazonia. Nature 339: 655-657.

Phillips, O. 1996. Some quantitative methods for analyzing ethnobotanical knowledge. Pages 171-197 in M. Alexiades, ed. Selected guidelines for ethnobotanical research: A field manual. New York Botanical Garden, New York.

, and A.H. Gentry. 1993. The useful plants of Tambopata, Peru: Statistical hypotheses tests with a new quantitative technique. Economic Botany 47:15-32.

Pieroni, A. 2001. Evaluation of the cultural significance of wild food botanicals consumed in northwestern Tuscany, Italy. Journal of Ethnobiology 21:89-104.
Pimentel, D., M. McNair, L. Buck, M. Pimentel, and J. Kamil. 1997. The value of forests to world food security. Human Ecology 25:91-120.

Reyes-García, V. 2001. Indigenous people, ethnobotanical knowledge, and market economy. A case study of the Tsimane' Amerindians, Bolivia. Ph.D. dissertation, University of Florida, Gainesville.

-, R. Godoy, V. Vadez, L. Apaza, E. Byron, E. Pérez, W. Leonard, and D. Wilkie. 2003. Ethnobotanical knowledge shared widely among Tsimane' Amerindians, Bolivia. Science 299:1707.

, V. Vadez, T. Huanca, W. Leonard, D. Wilkie. 2005. Knowledge and uses of wild plants: A comparative study in two Tsimane' villages in the Bolivian lowlands. Ethnobotany Research and Applications (in press).

Rossato, S. V.C., H. Leitao-Filho, and A. Begossi. 1999. Ethnobotany of Caicaras of the Atlantic Forest Coast (Brazil). Economic Botany 53:387395.

Ruddle, K., and R. Chesterfield. 1977. Education for traditional food procurement in the Orinoco Delta. University of California Press, Berkeley.

Stoffle, R.W., D.B. Halmo, M.J. Evans, and J.E. Olmsted. 1990. Calculating the cultural significance of American Indian plants: Paiute and Shoshone ethnobotany at Yucca Mountain, Nevada. American Anthropologist 92:416-432.

Turner, N.J., 1988. The importance of a rose: Evaluating the cultural significance of plants in Thompson and Lillooet Interior Salish. American Anthropologist 90:272-290.

Vadez, V., V. Reyes-García, L. Apaza, E. Byron, T. Huanca, W. Leonard, E. Pérez, and D. Wilkie. 2004. Does integration to the market threaten agricultural diversity? Panel and cross-sectional evidence from a horticultural-foraging society in the Bolivian Amazon. Human Ecology 32:635-646.

Zarger, R. 2002. Acquisition and transmission of subsistence knowledge by Q'eqchi' Maya in Belize. Pages 592-603 in J.R. Stepp, F.S. Wyndham, and R. Zarger, eds. Ethnobiology and biocultural diversity. International Society of Ethnobiology, Athens, Georgia. 